\title{
全血法によるヒスタミン遊離試験（HRT）を用いた スギ花粉症における個人差の検討
}

\author{
広島大学医学部耳鼻咽喉科 \\ 渡部浩石野岳志夜陣紘治 \\ 中国労災病院耳鼻咽喉科 \\ 田代亨 \\ メツダ病院耳鼻咽喉科 \\ 杉 本一郎
}

\section{USE OF WHOLE BLOOD HISTAMINE RELEASE TESTS TO DETERMINE INDIVIDUAL RESPONSIVENESS TO JAPANESE CEDAR POLLINOSIS}

\author{
Hiroshi Watanabe ${ }^{1)}$, Takashi Ishino ${ }^{1)}$, Toru Tashiro ${ }^{2)}$, \\ Ichiro Sugimoto ${ }^{3)}$, Koji Yajin ${ }^{1)}$
}

\author{
${ }^{1}$ Dept. Otorhinolaryngology, Hiroshima University School of Medicine, Hiroshima \\ ${ }^{2}$ Dept. Otorhinolaryngology, Chugoku Rosai General Hospital, Hiroshima \\ ${ }^{3}$ Dept: Otorhinolaryngology, Mazda Hospital, Hiroshima
}

The sensitivity, reactivity, and efficacy of treatment for Japanese cedar pollinosis varies from individual to individual. Specific serum IgE levels are not related to this responsiveness. The whole blood histamine release test (HRT) is based on the in vitro measurement of an immediate allergic reaction. This method, using peripheral whole blood, may be used to reveal the influence of not only specific $\operatorname{IgE}$ antibodies, but $\mathrm{IgG}_{4}$ and cytokines on the release of histamines from basophils.

Japanese cedar pollinosis patients with high specific serum IgE levels were divided into high class of HRT (hHRT) and low class HRT (1HRT) groups. No differences in age, sex, period of symptoms, first day of allergic symptoms (sensitivity), positivity for other specific IgE levels, and symptom score at the time of the first visit (reactivity) were observed between the two groups. Treatment with new antihistamines significantly improved the symptom score of the lHRT patients but not the hHRT patients. This result suggests that HRT is useful for estimating the efficacy of new anti-histamines and selecting an appropriate treatment.

In conclusion, these results indicate that HRT is not useful for determining the sensitivity or reactivity of patients with Japanese cedar pollinosis but is useful for estimating the efficacy of new anti-histamines 
treatments.

Key words: Japanese cedar pollinosis, histamine release test, individuality, responsiveness, efficacy of antihistamines

\section{はじめに}

スギ花粉症患者において，発症時期（感受性）および 重症度（反応性）などの過敏性の個人差が認められるこ とが報告されている1)。また日常診療において同一治療 によって改善が良好な例と不良な例とが存在することも しばしば経験することである。しかしながら，これらの 過敏性はスギ花粉症診断において汎用されているスギ特 異的 $\operatorname{IgE}$ 抗体価とは相関しない2)。

アレルギー学的検査法には皮膚試験, 特異的 $\operatorname{IgE}$ 抗体 の測定(CAP RAST 法, AlaSTAT 法など), 誘発試験, ヒスタミン遊離試験などがある。このうち in vitro の診 断法には特異的 IgE 抗体の測定, ヒスタミン遊離試験が ある。特異的 $\operatorname{IgE}$ 抗体の測定は血液中の $\operatorname{IgE}$ 抗体量を測 定しその存在をみているだけなのに対し, ヒスタミン遊 離試験は in vitroで抗原を添加し, 好塩基球に結合した $\operatorname{IgE}$ 抗体に抗原が結合することにより抗原抗体反応が起 こり，それに伴うケミカルメディエーターの遊離という 一連の生物学的反応を再現するものである ${ }^{3)}$ 。今回用い た全血法を用いたヒスタミン遊離試験（HRT）は従来の 洗浄白血球を用いる方法 ${ }^{4)} に$ 比べ, 少量の全血で検査が 行なえ, 同時に複数の抗原について検査が可能で, 保険 適応もとれており日常診療におるても使用できる検査法 である。また，全血を用いるため IgE 抗体以外の要因で ある, $\mathrm{IgG}_{4}$ 抗体, サイトカイン, ホルモンなどの因子の 関与を反映し, より患者の感作状態を総合的に反映して いることが考えられる。

今回，スギ花粉症患者に㧍いて HRT が過敏性の個人 差の指標となり得るかの検討を行い, 若干の知見が得ら れたので報告する。

\section{対象および方法}

スギ花粉飛散期に花粉症症状を訴えて中国労災病院耳 鼻咽喉科を受診した，1998年の22例および1999年の15例 を対象とした。

初診時に採血し, 吸入系 HRT (ルシカ ${ }^{\circledR} H R T$ )を測定 し，同時に1998年はAlaSTAT 法で1999年はCAP RAST 法にてスギおよびその他 15 種類の吸入抗原特異 的 $\operatorname{IgE}$ 抗体を測定した。

1998年および1999年の症例ともに，初診時から塩酸工
バスチン（ごく一部の症例で他の塩基性抗アレルギー内 服薬を使用）の常用量を投与し，眼症状を有する例には トラニラスト点眼薬を併用した。なお全例で内服，局所 ステロイド薬は使用していない。症状は下記の症状スコ ア表を用いてスコア化し初診時および投薬 $2 \sim 4$ 週間後 の受診時の問診で判定した。なお,症状程度分類には奥田 の分類が標準であるが, 本研究の検討時点においては重 症例の細かい判定に不向きな旧分類しか入手できなかっ たため，独自の症状スコアを作成した。

スギ花粉症症状スコア（カッコ内はスコア点数）

1）くしゃみ（1日のくしゃみ回数）

0 回 ( 0 )，1 5 回 ( 1 ), 6 10回 ( 2 ), 11 20回 ( 3 )，21～50回（4)，それ以上（ 5 ）

2) 鼻汁 ( 1 日の擤鼻回数)

0 回 ( 0 )，1 5 回 ( 1 )，6 10回 ( 2 ), 11 20回 ( 3 )，21～50回（4)，それ以上（5）

\section{3）鼻閉}

なし $(0)$ ，多少鼻づまりがある $(1) ，$ 片方がつまり， 息が苦しい（2），両方ともつまることが少しある(3)， 両方とも長時間完全につまっている

4) 目のかゆみ

なし（0)，すこしかゆい（1），中間のかゆさ（2), がまんできないかゆさ（3）

統計学的検討は， 2 群間の差の検定において対応のあ る場合は，Wilcoxon 符号付順位和検定を，対応のない 場合は，Mann-Whitney 検定を用いた。また相関関係の 検定には Spearman 順位相関係数の検定を用いた。

\section{結：果}

1. スギ HRT とスギ特異的 $\operatorname{IgE}$ 抗体の関係（図 1)

AlaSTATとの関係に扝いて $\mathrm{n}=22, \mathrm{r}=0.652$, $\mathrm{p}<0.05$ で有意な相関関係が得られた。しかし擬陰性が 19例中の 7 例 (36.8\%) に認められた。CAP RAST との 関係においても $\mathrm{n}=15, \mathrm{r}=0.555, \mathrm{p}<0.05$ で相関が得 られた。擬陰性は15例中の 5 例 $(33.3 \%)$ に認められた。 どちらの検討においてもスギ特異的 IgE抗体が比較的 高い症例の中で，スギ HRT のクラスが $0 ， 1$ あるいは 3，4 で，ある程度のまとまった群が認められ（図 1 , 斜線部)，スギ HRT クラス 0 ・ 1 群 (HRT 0， 1 群) およびスギ HRT クラス 3 ・4 群（HRT 3，4 群）の 2 


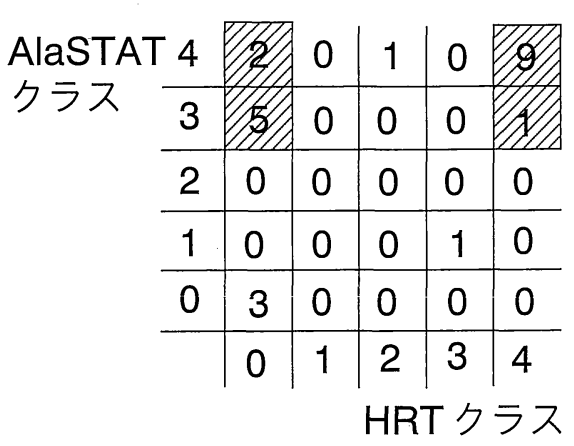

AlaSTAT

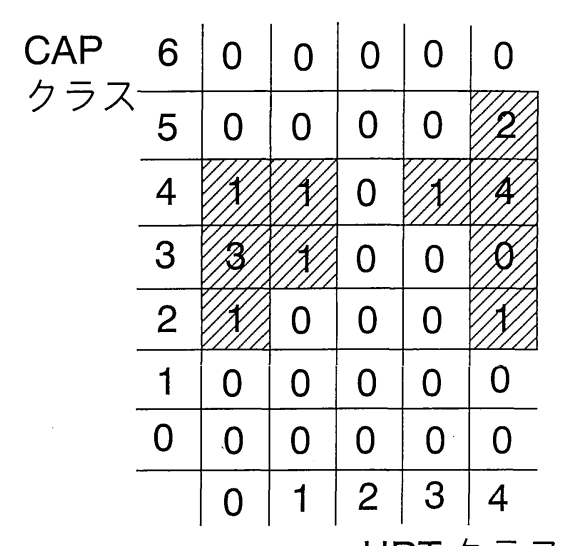

HRT クラス

図 1 スギ HRT とスギ AlaSTAT 抽゙ CAP RAST の関係

表 1 : スギ HRT クラス $0 ・ 1$ 群および HRT クラス $3 ・ 4$ 群の背景因子（N.S. : 有意 差なし)

\begin{tabular}{|c|c|c|c|}
\hline スギHRT クラス & $0 \cdot 1$ & \multicolumn{2}{|l|}{$3 \cdot 4$} \\
\hline $\begin{array}{r}\text { 症例数: } 98 \text { 年 } \\
99 \text { 年 }\end{array}$ & $\begin{array}{l}7 \text { 例 } \\
7 \text { 例 }\end{array}$ & $\begin{array}{r}10 \text { 例 } \\
8 \text { 例 }\end{array}$ & \\
\hline $\begin{array}{c}\text { スギ特異的 IgE クラス } \\
: \text { AlaSTAT } \\
\text { :CAP }\end{array}$ & $\begin{array}{l}3.29 \\
3.14\end{array}$ & $\begin{array}{l}3.90 \\
4.00\end{array}$ & $\begin{array}{l}(p<0.05) \\
(p<0.05)\end{array}$ \\
\hline 年齢 & 36.6 & 38.2 & (N.S.) \\
\hline 男女比 & $2: 5$ & $4: 5$ & (N.S.) \\
\hline 罹病期間 & 5.92 年 & 5.06 年 & (N.S.) \\
\hline $\begin{array}{r}\text { 症状発現日：98 年 } \\
99 \text { 年 }\end{array}$ & $\begin{array}{l}\text { 月初〜下旬 } \\
\text { 中〜3 月上旬 }\end{array}$ & $\begin{array}{r}2 \text { 月初 下 } \\
2 \text { 月中 } \sim 3 \text { 月 }\end{array}$ & $\begin{array}{l}\text { 旬 } \\
\text { 月旬 }\end{array}$ \\
\hline 他抗原陽性症例 & $14(57.1 \%)$ & $10 / 18(55.5$ & \%) (N.S.) \\
\hline
\end{tabular}

群に分類できた。以下の検討はこの 2 群間の比較で行っ た。

2. HRT 0, 1 群および HRT 3, 4 群の背景因子

表 1 に示すように, スギ特異的 $\operatorname{IgE}$ 抗体クラスは HRT 0，1群および HRT 3，4 群間で有意差を認め た。その他の年齢, 男女比, 罹病期間, 症状発現日, ス ギ以外の $\operatorname{IgE}$ 抗体陽性率に有意な差を認めなかった。

3. HRT 0, 1 群扔よび HRT 3, 4 群の初診時症状ス コア (図 2)

1998年および1999年の初診時症状スコアが確認できた HRT 0，1群11例，HRT 3，4群16例で検討した。発 症から初診までの期間は HRT 0，1 群が平均 11.2 日, HRT 3，4 群が平均15.1日で両群間に有意差を認めな かった。症状別の検討で鼻汁症状が HRT 0,1 群で有意 に高く，目のかゆみが HRT 3，4 群で有意に高かった。
くしゃみ，鼻閉症状扔よび症状スコアの合計点において は両群間で有意差を認めなかった。各年別の検討でもほ ぼ同じ傾向であった。

4. HRT 0,1 群抢よび HRT 3,4 群の抗アレルギー 薬投与による症状経過

図 3 に1998年のス求花粉飛散数（ロータリー型花粉捕 集器にて計測) と HRT 0, 1 群およびHRT 3, 4 群別 の症状経過を示す。HRT 0，1群では抗アレルギー薬 投与により症状の改善がみられるが，HRT 3，4 群で は症状の改善が見られない傾向が認められた。

図 4 は1998年および1999年の抗アレルギー薬治療によ る症状経過が追えた症例をまとめたものである（HRT 0，1群：9 例, HRT 3，4 群：9例)。HRT 0，1群 および HRT 3，4 群間の症状スコアは初診時には有意 差を認めなかったが，加療後には両群間で有意差が認め 


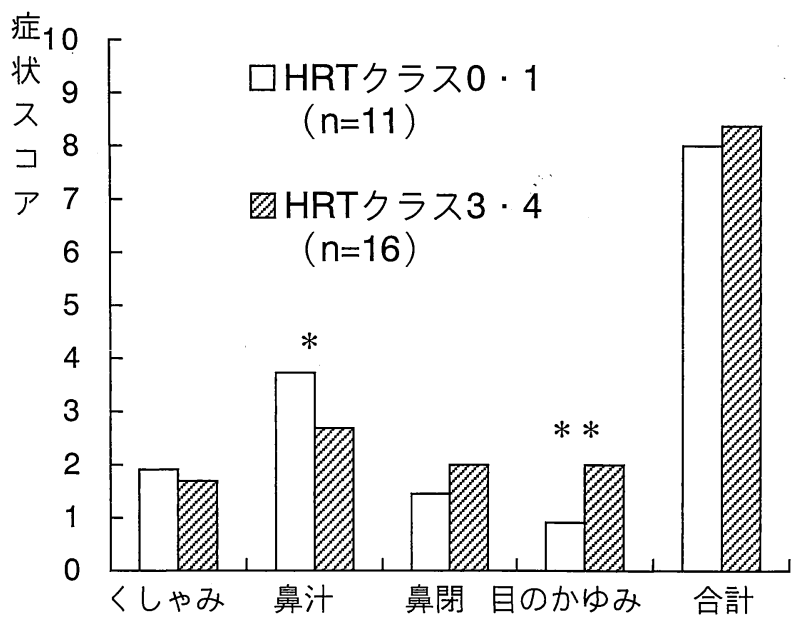

図2 スギHRTクラス $0 ・ 1$ 群およびHRT クラス 3 ・ 4 群の初診時症状スコア $\left(*: \mathrm{p}<0.05,{ }^{* *}\right.$ : $\mathrm{p}<0.01)$

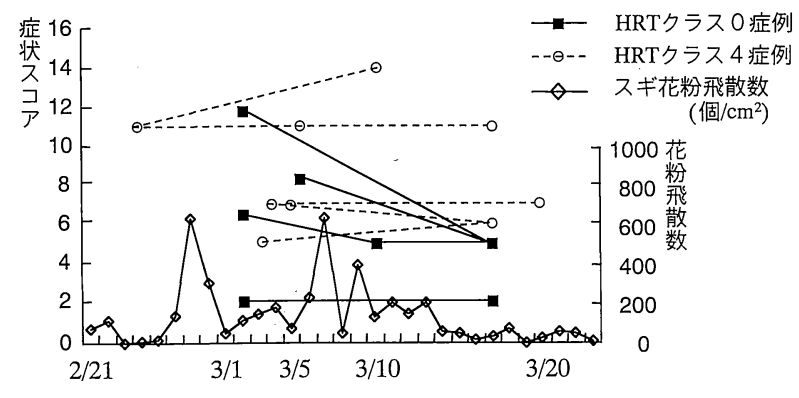

図 3 1998年におけるHRT クラス 0 症例および HRT クラス 4 症例の症状経過执よびスギ花粉飛散数

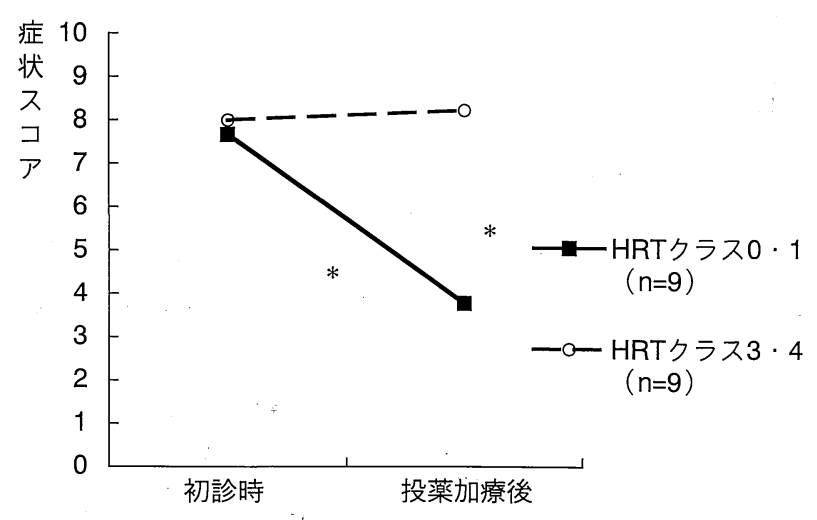

図4 スギHRTクラス $0 ・ 1$ 群およびHRTクラス $3 \cdot 4$ 群の抗アレルギー薬治療効果 $(*: \mathrm{p}<0.05)$

られた。またHRT 0,1 群は初診時と加療後の症状スコ アに有意差が認められたが, HRT'3，4群においては差 がみられなかった。

1998年(HRT 0, 1 群：4 例, HRT 3，4 群：5例) の検討では治療後の HRT 0，1群および HRT 3, 4 群 間のみに有意差が認められた。1999年(HRT 0， 1 群：
5 例, HRT 3，4 群：4 例)の検討では HRT 0， 1 群 の治療前後でのみ有意差が認められた。

症状別の検討では, HRT 0，1群は初診時の症状に おいて目のかゆみは少なく, HRT $0 ， 1$ 群における上 記の改善は主に鼻症状の改善によるものであった。 HRT 3, 4 群では鼻症状, 目のかゆみともに改善が認め られなかった。

\section{考察}

種々のアレルギー性疾患において原因抗原の特定など の臨床診断における HRT の有用性が報告 5 (6,7) されてい る。本研究の症例はスギ花粉飛散時期に花粉症症状を有 しており，スギ特異的 IgE 抗体陽性例はいずれもスギ花 粉症患者と考えられる。本研究においてスギ HRT とス ギ AlaSTAT およびCAP RAST の間に有意な相関が みられるもののスギ HRT の擬陰性率は $30 \%$ 以上に認め られており，スギ花粉症における原因抗原診断における HRT の有用性は低いものと考えられる。また，HRTの クラス 1 から 3 の症例が少なく，多くの症例がクラス 0 および 4 に分かれる傾向があるが, 過去の112検体の多数 例の報告5)においても全く同様の傾向が認められてお り，スギ HRT 所見の特徴と考えられる。

スギ花粉症には過敏性の個人差があることが報告され ている。花粉の飛散がまだ少数の早期から発症する例や 花粉飛散量が多くなって初めて発症する例などの発症時 “期 (感受性) の個人差がある。また，同じ花粉飛散数で も重症化する例がある一方で，比較的軽症で経過する例 が見られ重症度 (反応性) の個人差がある1)。これらの個 人差を把握できる方法があれば，発症時期や重症度にみ あった治療が行える事が考えられる。しかしながら，ア レルギー性疾患の診断に汎用される特異的 $\operatorname{IgE}$ 抗体価 はこれらの個人差と相関しない2)。

今回，スギ HRT とスギ特異的 $\operatorname{IgE}$ 抗体価との関連を みたところ，スギ花粉症症状を有し IgE 抗体価がある程 度高いものの中でも HRT クラスが低いものがかなりの 例数にみられた。HRT クラスが高いもの（HRT 3，4 群) およびHRT クラスが低いもの（HRT 0，1群）で ほぼ同程度の例数が認められたため, スギ花粉症の過敏 性の個人差に関連する因子をこの両群間で比較し, HRT が過敏性の個人差の指標になり得るかを検討し た。

両群間で年令, 男女比に差は認めなかった。スギ特異 的 $\operatorname{IgE}$ 抗体価は両群間で有意差を認めたが, クラスの平 均值では大きな差は認めなかった。罹病期間も 2 群間で 有意な差を認めず，罹病期間が長くなれば HRT スコア 
が高くなるというものではなく，HRT クラスの高低は ある程度個人差に基づくものと考えられた。症状発現時 期も 2 群間で差がなく, HRT によって発症時期（感受 性）の個人差を推定することは困難と思われた。

重複感作例の検討において, スギ単独感作例に比較し 他の抗原感作が合併し，その抗体価が増すほどスギ花粉 症の発症率が低下するという報告8)が西る。また同時に ダニ感作アレルギー性鼻炎患者において，ダニ抗原によ る下鼻甲介粘膜上皮擦過片からのヒスタミン遊離率が他 抗原の感作症例において低いことが示されている。この 要因として他の抗原 $\operatorname{IgE}$ 抗体量が多い例においては肥 満細胞表面に多くの他抗原 IgE 抗体が結合するため, 原 因抗原を添加しても化学伝達物質の遊離が起こりにくい ためであろうとしている8。本研究においては，スギ抗 原による末梢血中の好塩基球からのヒスタミン遊離が強 いHRT 3，4群および遊離が弱い HRT 0，1 群の両群 間で他抗原感作率に差は認めなかった。つまりスギ以外 の特異的 IgE 抗体が陽性であるからといって，スギによ る末梢血中好塩基球の脱顆粒が抑制されることはなかっ た。

重症度との関連においては，両群間で初診時の合計症 状スコアに差を認めなかった。これら 2 群間で発症から 初診までの日数にも有意差を認めていない。このことか ら, HRTによってスギ花粉症発症後の重症度（反応性） の個人差を推定することは困難と思われた。この理由と しては, HRT が血液中の好塩基球の反応をみているの に対して，スギ花粉症状は主に鼻腔粘膜あるいは眼球結 膜の肥満細胞の反応に起因するため, HRT は個体の感 作および反応性をある程度反映するものの, 局所におけ る肥満細胞の反応を直接に反映していないことなどが考 えられるが, 詳細は不明である。また, 症状別の検討に おいて, 鼻汁症状は HRT 0, 1 群で, 眼症状は HRT 3, 4 群で有意に強かったが, くしゃみ, 鼻閉症状は 2 群間 で差を認めなかった。この理由としては, 鼻症状は主に 上皮層の粘膜型肥満細胞の活性化で発症するのに対し, 眼球結膜の肥満細胞はほとんどが結合組織型肥満細胞で あり ${ }^{9)}$ これらの肥満細胞の反応性の相違を HRT が示し た可能性などが考元られるが,やはり詳細は不明である。

次に，抗ヒスタミン作用を有する抗アレルギー薬（塩 基性抗アレルギー薬)を投与し治療効果の検討を行った。 HRT 0，1群においては有意な症状の改善が得られた が, HRT 3, 4 群では症状に変化は認められなかった。 これらの 2 群間での投薬前の症状スコアには差がみられ なかった。以上のことから, HRTにより抗アレルギー 薬による治療効果の個人差が推定できる可能性が示唆さ
れる。つまり, HRT 0, 1 群においては症状出現後から の抗アレルギー薬治療で症状がコントロールでき，一方 でHRT 3，4 群に扔いては発症後からの抗アレルギー 薬治療では症状のコントロールがつかず，花粉飛散前早 期からの予防的治療やステロイドなど他の薬剤の併用が 必要になるなどの事が推定できる可能性である。なお HRT は結果が得られるまでに 3 ～5 日を要するため, 初診時からの治療には反映できない。また上述したが, HRT クラスの高低は罹病期間と関係せず，HRT はあ る程度患者の恒常的反応性をみているとも考元られ, 翌 年からの治療にも反映できる可能性がある。しかしなが ら, スギ HRT の経年変化については今後検討を要する。 また, 今回のスギ HRT の測定時期はスギ花粉飛散季節 中の症状出現後のもので，スギ花粉に対して活性化され た時期のものであり, 花粉飛散季節外の HRT 測定では 異なる結果が出るものと思われる。

HRT は好塩基球のヒスタミン遊離をみる検査である が, 同程度の IgE 抗体レベルの症例において HRT クラ ス,つまりヒスタミン遊離量に差が得られた理由として は好塩基球膜表面に結合した $\operatorname{IgE}$ 抗体の状態, $\operatorname{IgG}_{4}$ 抗 体などの関与, 補体の関与などの違いが考えられる。ま た好塩基球におけるプライミング作用の関与も考えられ る。プライミング作用とはそれ自体ではヒスタミン遊離 作用がないが，その物質の短時間の前処理によって活性 化刺激のシグナルを増強し，メディエーター遊離能が増 強される作用である。好塩基球に対しこの作用を有する 物質として, IL3, IL5, GM-CSF, IFN などのサイトカ インが知られている(10)。またヒ卜培養マス卜細胞におい てもIL3，IL4，IL5，IL6，IFN- $\gamma$ が IgE 抗体依存性の

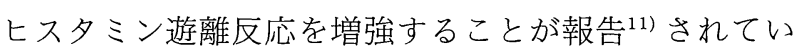
る。このことから, HRT クラスが高い例では低い例に比 較して血中に抢けるこれらのサイトカインが多く,プラ イミング作用によってヒスタミン遊離が増強されている 可能性も考元られる。本研究において, HRT クラスの 高低で抗アレルギー薬による治療効果に差がみられた理 由として, 上述した $\operatorname{IgG}_{4}$ 抗体, 補体, サイトカインなど の関与が強い症例では抗アレルギー薬による治療効果が 弱いなどのことが想定されるが，今後，サイトカインの 測定を含めた検討が必要である。

いずれにしても，本研究は少数例の検討であるが，ス ギ花粉症患者において HRT を施行し好塩基球のヒスタ ミン遊離状態をみることによって, 個々の患者の抗アレ ルギー薬の治療効果を推定し, 治療の選択に反映できる 可能性が示唆されるため, 今後症例数を増やした検討が 必要と思われる。 


\section{参考文献}

1）馬場廣太郎：鼻粘膜の抗原に対する過敏性.耳鼻臨 床 $91: 209-217,1998$.

2 ）馬場廣太郎：スギ花粉少量連続飛散による鼻粘膜過 敏性, 過敏症状の変化.アレルギー科 1 ：287298, 1996.

3 ) 大山邦夫, 倉持健太郎, 芹澤 領, 他：アレルギー 診断薬 HRT の基礎的検討. 医学と薬学 31 : 113125, 1994 .

4) Diamant B, Patkar S: Histamine release from washed whole blood. A method suitable for routine diagnosis of type I allergy. Int Arch Allergy Appl Immunol 67 : 13- 17, 1982.

5 ）宮本昭正，秋山一男，金子富志人，他：多項目七ス タミン遊離試験法 HRT の特性とその臨床的意義に ついて. 医学と薬学 31:127-140, 1994.

6 ) 田部一秋, 金子富志人, 川村則行, 他：全血法によ る多種抗原同時ヒスタミン遊離試験の臨床的検討一 吸入誘発試験との相関について一.アレルギー $43: 527-534,1994$

7 ) Mamiya S, Ito H, Suzuki M, et al : Clinical evaluation of histamine release test: a novel method for identifying allergens from the whole blood of allergic patients. Acta Otolaryngol (Stockh); Suppl 525: 93-97, 1996.

8 ）大塚博邦, 國友万由美: 鼻アレルギー及び花粉症の 診断における試験管内 IgE 測定の意義について一 鼻粘膜肥満細胞七スタミン遊離の視点一. 日鼻誌 37:92-97, 1998.

9) Irani A M, Butrus S I, Tabbara K F, et al: Human conjunctival mast cells: distribution of MCT and MCTC in vernal conjunctivitis and giant papillary conjunctivitis. J Allergy Clin Immunol 86: 34-40, 1990.

10）平井浩一：ヒト好塩基球のプライミングと活性化. アレルギー科 $5: 377-381,1998$.

11) Yanagida $M$, Fukamachi $H$, Ohgami $K$, et al : Effects of T-helper 2-type cytokines, interleukin3 (IL-3), IL-4, IL-5, and IL-6 on the survival of cultured human mast cells. Blood 86 : 3705-3714, 1995.

（2001年 6 月 11 日受稿，2001年 9 月 28 日受理）

別刷請求先 $=734-8851$ 広島市南区霞1-2-3

広島大学医学部耳鼻咽喉科学教室 渡部 浩

Tel : 082-257-5252 Fax :082-257-5254 